\title{
RELATIONSHIP BETWEEN EMOTIONAL INTELLIGENCE WITH STRESS LEVEL OF FIRST YEAR STUDENT IN NURSING PROGRAM STUDY MEDICAL FACULTY HASANUDDIN UNIVERSITY
}

\author{
Muhnia $^{1}$, Wa Ode Nur Isnah ${ }^{2}$, Hapsah $^{3}$ \\ 1,2,3, Nursing Study Program, Universitas Hasanuddin Makassar \\ e-mail: niamuhnia@gmail.com
}

\begin{abstract}
Introduction: Stress is a thing that can be experienced by anyone, including first year students. Every person are different in coping with stress, one of the factor is emotional intelligence. This study aimed to investigate the relationship between emotional intelligence and stress level of first year students in Nursing Program Study Medical Faculty Hasanuddin University. Methode: The study design was cross sectional approach. This research was conducting by filling the quostionnaire of emotional intelligence and stress, are measured by emotional intelligence adolescent and Depression Anxiety Scale (DASS 42).Result: In this study showed that there is a relationship between emotional intelligence and stress level of first year students, with significant value of $\mathrm{p}$ 0.036. Individual with high emotional intelligence, showed the lower stress level. The dimensions of emotional intelligence that may have be contributed to the stress of students are ability to manage emotions and motivation. Conclusions: It is concluded that there is a negative relationship between emotional intelligence and stress level of first year students. Therefore, it is necessary to have a program that can develop emotional intelligence for first year student.
\end{abstract}

Key words : stress, emotional intelligence, first year student

\section{PENDAHULUAN}

Mahasiswa adalah seseorang yang belajar di perguruan tinggi (KBBI, 2016).Pada saat memasuki dunia perkuliahan untuk pertama kalinya, mahasiswa dipertemukan dengan dunia kampus yang baru.Akibat transisi dalam lingkungan universitas, maka mahasiswa tahun pertama rentan mengalami stres (Maulana et al., 2014).

Penelitian yang dilakukan oleh Reddy et al. (2015) di Fakultas Kedokteran Katuri, India Selatan, menemukan bahwa 3,5\% mahasiswa mengalami stres rendah, $21,7 \%$ mengalami stres sedang, $38,5 \%$ mengalami stres tinggi, dan 35,7\% mengalami stres yang sangat tinggi. Sedangkan, penelitian yang dilakukan Nurliyanti (2014) di Program Studi Ilmu Keperawatan Fakultas Kedokteran
Universitas Hasanuddin (PSIK FK $\mathrm{UH}$ ), menemukan bahwa mahasiswa semester awal 41,4\% mengalami tingkat stres sedang dan 6,9\% mengalami tingkat stres tinggi.

Stres dapat berdampak negatif jika tidak ditemukan solusi yang tepat. Perasaan negatif atau terancamnya kesejahteraan emosional dapat timbul apabila seseorang tidak dapat beradaptasi dengan stres yang dirasakannya (Potter \& Perry, 2005). Penelitian yang dilakukan oleh Sohail (2013) menunjukkan bahwa dampak stres pada mahasiswa, yaitu mahasiswa yang memiliki tingkat stres tinggi 80\% kemungkinan mengalami perubahan kesehatan yang serius, mahasiswa yang memiliki tingkat stres sedang 50\% kemungkinan mengalami perubahan kesehatan, dan mahasiswa yang memiliki tingkat stres rendah 30\% 
kemungkinan mengalami perubahan kesehatan.

Penyebab stres pada mahasiswa tahun pertama dapat disebabkan karena berbagai hal.Penelitian yang dilakukan oleh Nurliyanti (2014) di PSIK FK UH menyatakan bahwa penyebab stres pada mahasiswa tahun pertama diantaranya padatnya jadwal perkuliahan dan kurikulum di tahun pertama daripada tahun lanjutan.

Setiap individu berbeda dalam menghadapi stres. Perbedaan individu dalam menyesuaikan diri terhadap stres ini dipengaruhi oleh berbagai faktor, diantaranya inteligensi, kreativitas, kecerdasan emosional, pengaruh lingkungan, pendidikan, pengembangan diri, usia, dan spiritual (Ninggalih, 2013; Yadav, Khanna, \& Singh, 2016). Penelitian yang dilakukan oleh Nafiati (2015) menemukan bahwa stres kuliah pada mahasiswa dipengaruhi oleh lingkungan belajar dan kecerdasan emosional. Kecerdasan emosional ini mencakup kemampuan seseorang dalam mengenali emosi diri, mengelola emosi, memotivasi diri, mengenali emosi orang lain (empati), dan membina hubungan dengan orang lain (Goleman, 2015).

Kecerdasan emosional dapat mempengaruhi stres karena seseorang dengan kecerdasan emosional yang tinggi dapat mengatur, mentolerir, mengelola, dan mengendalikan emosi, bahkan ketika mereka marah atau merasa stres (Abdollahi et al.,
2016).Selain itu, seseorang dengan kecerdasan emosional yang tinggi dapat menerapkan strategi koping yang aktif dan efektif ketika berhadapan dengan stres (Mi-Ran \& Su-Jeong, 2015).

Terkait pentingnya kecerdasan emosional dalam mengurangi stres seseorang, maka peneliti tertarik untuk melakukan penelitian tentang hubungan kecerdasan emosional dengan tingkat stres mahasiswa tahun pertama di Program Studi Ilmu Keperawatan Fakultas Kedokteran Universitas Hasanuddin.

\section{METODE}

Penelitian ini merupakan penelitian analitik, dimana metode yang digunakan adalah rancangan cross sectional.Penelitian ini menganalisis hubungan variabel independen yaitu kecerdasan emosional dengan variabel dependen yaitu tingkat stres mahasiswa tahun pertama.Populasi dalam penelitian ini adalah mahasiswa tahun pertama kelas regular angkatan 2016 di PSIK FK UH yang berjumlah 91 orang, dimana sampel yang diambil sebanyak 74 responden. Teknik pengambilan sampel yang digunakan adalah simple random sampling.

Instrumen yang digunakan untuk mengumpulkan data dalam penelitian ini, yaitu kusioner alat ukur kecerdasan emosi remaja dan Depression Anxiety Scale (DASS 42).

\section{HASIL}

\begin{tabular}{lccccc}
\hline & Mean & Median & SD & Minimum & Maksimum \\
\hline Umur (tahun) & 17,84 & 18,00 & 0,683 & 16 & 20 \\
\hline
\end{tabular}

Tabel 1. Distribusi rerata karakteristik responden berdasarkan usia pada mahasiswa tahun pertama PSIK FK UH, kelas regular angkatan 2016 (n=74).

Berdasarkan tabel tersebut, usia rata-rata responden adalah 17,84 tahun. Usia tertua responden adalah
20 tahun dan usia termuda adalah 16 tahun (tabel 1.). 


\begin{tabular}{|c|c|c|}
\hline Karakteristik & Frekuensi (f) & Persentasi (\%) \\
\hline \multicolumn{3}{|l|}{ Jenis Kelamin: } \\
\hline Laki-laki & 5 & 6,8 \\
\hline Perempuan & 69 & 93,2 \\
\hline \multicolumn{3}{|l|}{ Tinggal Dengan: } \\
\hline Sendiri (kost) & 29 & 39,2 \\
\hline Dengan saudara (kontrakan) & 14 & 18,9 \\
\hline Dengan keluarga & 8 & 10,8 \\
\hline Dengan orang tua & 23 & 31,1 \\
\hline \multicolumn{3}{|l|}{ Asal Daerah: } \\
\hline Makassar & 22 & 29,7 \\
\hline Luar Makassar & 54 & 70,3 \\
\hline \multicolumn{3}{|l|}{ Frekuensi Pulang Kampung: } \\
\hline $1 \mathrm{x}$ seminggu & 5 & 9,8 \\
\hline $1-2 x$ sebulan & 10 & 19,6 \\
\hline 1-2x selama kuliah & 8 & 15,7 \\
\hline Belum pernah & 28 & 54,9 \\
\hline \multicolumn{3}{|l|}{ Penghasilan Keluarga: } \\
\hline < UMR (Upah Minimum Regional) & 33 & 44,6 \\
\hline$\geq \mathrm{UMR}$ & 41 & 55,4 \\
\hline \multicolumn{3}{|l|}{ Alur Pengkaderan: } \\
\hline Ya & 74 & 100 \\
\hline Tidak & 0 & \\
\hline \multicolumn{3}{|c|}{ Hal dari Senior yang Membuat Terganggu: } \\
\hline Pengumpulan & 21 & 28,4 \\
\hline Emosional & 6 & 8,1 \\
\hline Tugas & 3 & 4,1 \\
\hline Cuek saat diberi salam & 1 & 1,4 \\
\hline Membayar untuk kegiatan & 1 & 1,4 \\
\hline Diminta memilih satu hal & 1 & 1,4 \\
\hline Tidak ada & 41 & 55,4 \\
\hline \multicolumn{3}{|l|}{ Jadwal Padat: } \\
\hline $\mathrm{Ya}$ & 55 & 74,3 \\
\hline Tidak & 19 & 25,7 \\
\hline \multicolumn{3}{|l|}{ Jadwal Lain selain Akademik: } \\
\hline Ya & 74 & 100 \\
\hline Tidak & 0 & \\
\hline \multicolumn{3}{|l|}{ Takut Dosen: } \\
\hline $\mathrm{Ya}$ & 20 & 27,0 \\
\hline Tidak & 54 & 73,0 \\
\hline \multicolumn{3}{|l|}{ Bekerja: } \\
\hline $\mathrm{Ya}$ & 1 & 1,4 \\
\hline Tidak & 73 & 98,6 \\
\hline
\end{tabular}

Tabel 2. Distribusi frekuensi berdasarkan karakteristik mahasiswa tahun pertama PSIK FK UH, kelas reguler angkatan 2016 ( $\mathrm{n}=74)$.

\begin{tabular}{lcccccc}
\hline \multirow{2}{*}{ Kecerdasan Emosional } & \multicolumn{7}{c}{ Kategori } \\
\cline { 2 - 7 } & \multicolumn{2}{c}{ Rendah } & \multicolumn{2}{c}{ Sedang } & \multicolumn{2}{c}{ Tinggi } \\
\cline { 2 - 7 } & $\mathbf{f}$ & \% & F & \% & f & \% \\
\hline Kecerdasan emosional & 2 & 2,7 & 39 & 52,7 & 33 & 44,6 \\
\hline Mengenal emosi diri & 4 & 5,4 & 29 & 39,2 & 41 & 55,4 \\
\hline Mengelola emosi & 10 & 13,5 & 53 & 71,6 & 11 & 14,9 \\
\hline Motivasi & 0 & 0 & 31 & 41,9 & 43 & 58,1 \\
\hline Empati & 0 & 0 & 19 & 25,7 & 55 & 74,3 \\
\hline Membina hubungan & 2 & 2,7 & 45 & 60,8 & 27 & 36,5 \\
\hline
\end{tabular}

Tabel 3. Distribusi frekuensi kecerdasan emosional pada mahasiswa tahun pertama PSIK FK UH, kelas reguler angkatan $2016(n=74)$ 
Tabel 2. menunjukkan bahwa mayoritas responden berjenis kelamin perempuan, yakni 69 orang $(93,2 \%)$. Hampir sebagian responden tinggal sendiri (kost), yakni 29 orang $(39,2 \%)$.

Mayoritas dari responden juga berasal dari luar Makassar, yakni 54 orang $(70,3 \%)$. Sebagian besar responden yang berasal dari luar Makassar belum pernah kembali ke daerah asal mereka selama kuliah, yakni 28 orang (54,9\%). Penghasilan keluarga pada responden terbanyak berada di atas UMR (upah minimum regional), yakni 41 orang $(55,4 \%)$. Seluruh responden yakni 74 orang (100\%) mengikuti alur pengkaderan sebagai mahasiswa baru dan 41 orang diataranya $(55,4 \%)$ tidak merasa terganggu dengan hal-hal yang biasanya dilakukan oleh senior mereka. 55 orang $(74,3 \%)$ merasakan jadwal perkuliahan mereka padat, dimana selain jadwal perkuliahan, mereka juga memiliki jadwal lain di luar jam kuliah. Sebagian besar responden, yakni 54 orang $(73,0 \%)$ tidak takut dengan dosen mereka dan hampir seluruh mahasiswa, yakni 73 orang $(98,6 \%)$ tidak bekerja.

Tabel 3. menunjukkan bahwa 33 orang $(44,6 \%)$ memiliki kecerdasan emosional yang tinggi, 39 orang $(52,7 \%)$ memiliki kecerdasan emosional yang sedang, dan 2 orang $(2,7 \%)$ yang memiliki kecerdasan emosional yang rendah. Jadi, dapat disimpulkan bahwa lebih dari setengah responden memiliki kecerdasan emosional yang sedang. Sedangkan, dimensi kecerdasan emosional untuk kemampuan mengenal emosi diri, lebih dari setengah responden berada pada kategori tinggi, yakni 41 orang (55,4\%). Sebagian besar responden memiliki kemampuan mengelola emosi yang sedang, yakni 53 orang $(71,6 \%)$. Lebih dari setengah responden memiliki motivasi diri yang tinggi, yakni 43 orang $(58,1 \%)$. Mayoritas responden memiliki empati yang tinggi, yakni 55 orang $(74,3 \%)$. Serta sebagian besar responden yang memiliki kemampuan dalam membina hubungan dengan orang lain pada kategori sedang, yakni 45 orang $(60,8 \%)$.

\begin{tabular}{lcc}
\hline \multicolumn{1}{c}{ Stres } & Frekuensi (f) & Persentasi (\%) \\
\hline Normal & 34 & 45,9 \\
Ringan & 20 & 27 \\
Sedang & 12 & 16,2 \\
Berat & 8 & 10,8 \\
\hline
\end{tabular}

Tabel 4. Distribusi frekuensi tingkat stres pada mahasiswa tahun pertama PSIK FK UH, kelas reguler angkatan $2016(n=74)$

\begin{tabular}{lcc}
\hline \multicolumn{1}{c}{ Stres } & Frekuensi (f) & Persentasi (\%) \\
\hline Normal & 34 & 45,9 \\
Ringan & 20 & 27 \\
Sedang & 12 & 16,2 \\
Berat & 8 & 10,8 \\
\hline
\end{tabular}

Tabel 5. Uji spearman hubungan kecerdasan emosional dengan stres mahasiswa tahun pertama PSIK FK UH $(n=74)$

\begin{tabular}{ccc}
\hline Uji Korelasi & Nilai $\boldsymbol{r}$ & Nilai $\boldsymbol{p}$ \\
\hline Mengenal Emosi & -0.035 & 0,765 \\
Mengelola Emosi & -0.285 & 0,014 \\
Motivasi & -0.299 & 0,010 \\
Empati & -0.151 & 0,200 \\
Membina Hubungan & 0.001 & 0,991 \\
\hline
\end{tabular}

Tabel 6. Uji spearman hubungan mengenal emosi, mengelola emosi, motivasi, empati, dan membina hubungan dengan tingkat stres mahasiswa tahun pertama PSIK FK UH $(n=74)$ 
Tabel 5. memperlihatkan bahwa dengan menggunakan uji spearman diperoleh nilai $\mathrm{p}=0,036$. Nilai ini lebih kecil daripada a $(0,05)$, yang berarti terdapat hubungan antara kecerdasan emosional dengan tingkat stres mahasiswa tahun pertama.

Tabel 6. memperlihatkan bahwa dengan menggunakan uji spearman, dimensi dari kecerdasan emosional yang berhubungan dengan stres adalah mengelola emosi dan motivasi, dimana nilai $\mathrm{p}=0,014$ pada hubungan antara mengelola emosi dengan stres dan nilai $\mathrm{p}=0,010$ pada hubungan antara motivasi dengan stres.

\section{PEMBAHASAN}

\section{Karakteristik Responden Mahasiswa Tahun Pertama}

Frekuensi usia terbanyak adalah 18 tahun. Karena lumrahnya usia pada mahasiswa tahun pertama adalah 18 tahun, dimana sebelumnya mereka telah melewati berbagai macam tingkat pendidikan.Dimana pada usia tersebut, mereka mulai mencari identitas diri dan memikirkan tentang masa depan. Hasil penelitian ini sejalan dengan penelitian yang dilakukan oleh Nurliyanti (2014) yang menemukan bahwa usia pada mahasiswa tahun pertama terbanyak berada pada usia 18 tahun. Pada usia remaja terjadi perubahan, baik secara biologis, kognitif, dan sosial-emosional, serta proses berpikir abstrak sampai pada kemandirian (Learner \& Steinberg, 2009).

Mahasiswa tahun pertama di PSIK FK UH didominasi oleh perempuan. Hasil penelitian ini sejalan dengan penelitian yang dilakukan oleh Nurliyanti (2014) yang menemukan bahwa perempuan lebih mendominasi di PSIK FK UH. Hal ini kemungkinan dapat disebabkan karena perawat merupakan suatu profesi yang membutuhkan keahlian untuk merawat manusia nantinya. Dimana keahlian merawat identik dengan perempuan. Keperawatan dikenal dengan istilah 'mother instinc' yang berarti naluri keibuan, naluri untuk memberikan perlindungan, dan naluri sosial (Asmadi, 2008).

Mahasiswa tahun pertama di PSIK UH, kebanyakan tinggal sendiri (kost). Hasil penelitian ini sejalan dengan penelitian yang dilakukan oleh Nurliyanti (2014) yang menemukan bahwa kebanyakan mahasiswa tahun pertama tinggal sendiri (kost). Hal ini dapat disebabkan karena kebanyakan dari mereka juga berasal dari luar Makassar, sehingga mereka memilih untuk tinggal sendiri (kost). Selain itu, kemungkinan dari mereka juga ingin belajar untuk hidup mandiri. Sebagai remaja, mahasiswa mulai berpikir untuk mandiri (Santrock, 2003).

Sebagian besar mahasiswa tahun pertama di PSIK FK UH berasal dari luar Makassar. Seperti penelitian yang dilakukan oleh (Nurliyanti, 2014) yang menemukan bahwa kebanyakan mahasiswa tahun pertama berasal dari luar Makassar. Hal ini kemungkinan dapat disebabkan karena di daerah asal mereka tidak ada Universitas ataupun jurusan yang mereka inginkan.

Mahasiswa yang berasal dari luar Makassar, lebih dari setengahnya belum pernah pulang kampung. Hal ini kemungkinan dapat disebabkan karena jauhnya asal daerah mereka dan waktu liburan yang tidak terlalu panjang, sehingga tidak memungkinkan untuk mereka kembali ke daerah asalnya. Selain itu, untuk kembali ke daerah asalnya juga membutuhkan biaya.

Lebih dari setengah mahasiswa memiliki penghasilan keluarga di atas UMR. Hal ini kemungkinan dapat disebabkan karena pendidikan orang tuanya yang juga tinggi dan pekerjaan yang memadai, sehingga penghasilan keluarga mereka mencukupi.

Seluruh mahasiswa tahun pertama di PSIK FK UH mengikuti pengkaderan. Pengkaderan merupakan suatu proses, dimana mahasiswa tahun pertama dibentuk untuk menjadi kader.

Beberapa mahasiswa tahun pertama merasa terganggu dengan halhal yang dilakukan oleh seniornya, 
seperti pengumpulan yang mendadak sehingga mengambil waktu mereka, sifat emosional dari senior (berbicara dengan nada tinggi dan marah tanpa alasan yang jelas), tugas di luar tugas akademik, tidak membalas salam saat disapa, membayar untuk kegiatan yang akan dilakukan, serta diminta memilih satu hal seperti memilih untuk mengikuti kegiatan beasiswa bidikmisi atau kegiatan himpunan.

Jadwal perkuliahan yang ada di

PSIK FK UH membuat sebagian besar mahasiswa tahun pertama merasa bahwa jadwal perkuliahan mereka padat. Hal ini kemungkinan dapat dikarenakan cara belajar saat ini berbeda dengan sewaktu SMA. Dimana pada saat SMA, siswa menerima materi secara langsung yang diberikan gurunya, sedangkan di perkuliahan saat ini mahasiswa diharapkan lebih aktif lagi untuk mencari materi-materi mengenai perkuliahannya.

Tidak hanya jadwal akademik, seluruh mahasiswa tahun pertama juga memiliki jadwal lain di luar akademiknya, yaitu alur pembinaan. Alur pembinaan tersebut, antara lain: Orkesrek (olahraga, kesenian, dan rekreasi), pengumpulan, seminar, bazar, dan sebagainya. Selain itu ada pula club-club yang mereka ikuti, seperti FNC (Faal Nursing Club), NRC (Nursing Research Club), NEC (Nursing English Club), dan Jurnalistik. Ada pula mahasiswa yang memiliki kegiatan keagamaan, seperti SAINS, mentoring, tarbiyah, dan organisasi keagamaan di gereja. Tidak hanya kegiatan di lingkup Prodi, kegiatan di lingkup Universitas pun seperti UKM, diikuti oleh beberapa mahasiswa tahun pertama.

Sebagai mahasiswa tahun pertama, beberapa mahasiswa takut kepada dosen, namun kebanyakan dari mereka tidak merasa takut kepada dosen, mereka hanya merasa segan. Mahasiswa yang merasa takut kepada dosennya, dapat disebakan karena jika mereka berbuat kesalahan maka dosen akan merasa tersinggung, sehingga dapat berdampak pada nilai mereka.
Hampir seluruh mahasiswa tahun pertama di PSIK FK UH tidak bekerja. Dari penelitian ini didapatkan 1 orang yang bekerja, dimana mahasiswa yang bekerja tersebut memiliki usaha sendiri. Menurut peneliti, kebanyakan mahasiswa tidak bekerja karena mereka ingin fokus pada perkuliahannya.

\section{Gambaran Kecerdasan Emosional Mahasiswa Tahun Pertama}

Pada hasil penelitian ini didapatkan bahwa lebih dari setengah responden memiliki kecerdasan emosional yang sedang. Penelitian yang dilakukan oleh Fadilah \& Suleeman (2013) juga menemukan bahwa mahasiswa Fakultas Psikologi Universitas Indonesia, berada pada kategori sedang, yang berarti seorang individu tidak selalu dapat mengenali emosinya sendiri dan tidak selalu berhasil menjelaskan emosi orang lain secara akurat.

Kecerdasan emosional terdiri dari beberapa dimensi, yaitu kemampuan mengenali emosi diri, mengelola emosi, motivasi, empati dan membina hubungan dengan orang lain. Pada tabel 3.menunjukkan bahwa lebih dari setengah responden memiliki kemampuan mengenali emosi diri yang tinggi. Hal ini berarti mahasiswa tahun pertama di PSIK FK UH mampu untuk mengenali emosinya sendiri, sehingga mereka mampu mengetahui apa yang sedang mereka rasakan. Goleman (2015) menyatakan bahwa seseorang yang memiliki keyakinan yang lebih dengan perasaannya dapat menjalani hidup dengan lebih baik, karena mereka dapat mengambil keputusan-keputusan dalam setiap permasalahannya.Hal ini senada pula dengan penelitian yang dilakukan oleh Prasetiyo \& Andriani (2011) yang menemukan bahwa semakin tinggi kecerdasan emosi seseorang maka semakin tinggi pula tingkat kepuasan hidupnya dan kegembiraannya.

Dimensi yang kedua, yaitu kemampuan mengelola emosi. Pada 
tabel 3. menunjukkan bahwa mayoritas responden memiliki kemampuan mengelola emosi yang berada pada kategori sedang. Tridhonanto (2009) menyatakan bahwa seseorang yang mampu mengelola perasaanya dapat mengatasi rasa takut, cemas, amarah dan kesedihan yang dirasakannya dengan cara-cara yang tepat.

Dimensi kecerdasan emosional yang ketiga, yaitu kemampuan memotivasi diri.Pada tabel 3.menunjukkan bahwa lebih dari setengah responden memiliki kemampuan motivasi diri yang berada pada kategori tinggi. Goleman (2015) menyatakan bahwa seseorang dengan harapan yang tinggi tidak akan menyerah dalam menghadapi tantangan walaupun terjebak dalam kecemasan atau depresi. Hasil pada penelitian ini sejalan dengan penelitian yang dilakukan oleh Andriani (2011) yang menemukan bahwa mahasiswa keperawatan STIKES Dian Husana Mojokerto, mempunyai motivasi yang tinggi yakni 28 orang (40\%). Motivasi belajar tersebut berbanding lurus dengan indeks prestasi mahasiswa yang sangat memuaskan.

Dimensi kecerdasan emosional yang keempat, yaitu empati. Pada tabel 3. menunjukkan bahwa mayoritas responden memiliki empati yang tinggi. Empati dibangun berdasarkan kesadaran diri, semakin terbuka dengan emosi diri sendiri, maka semakin terampil dalam membaca perasaan orang lain (Goleman, 2015). Hasil penelitian ini sejalan dengan penelitian yang dilakukan oleh Nugroho, Pasiak, \& Tanudjaja (2016) yang menemukan bahwa empati pada mahasiswa Fakultas Kedokteran Universitas Sam Ratulangi sebagian besar berada pada kategori tinggi, yakni $67 \%$. Kemampuan untuk berempati merupakan hal yang penting dari perkembangan sosial dan emosional yang dapat berdampak pada sikap individu terhadap orang lain.

Dimensi yang kelima yaitu kemampuan membina hubungan dengan orang lain. Pada tabel 3. menunjukkan bahwa lebih dari setengah responden memiliki kemampuan membina hubungan dengan orang lain yang berada pada kategori sedang. Goleman (2015) menyatakan bahwa kemampuan untuk membina hubungan ini diperlukan agar seseorang dapat berinteraksi dengan orang lain di sekitarnya.

\section{Gambaran Tingkat Stres Mahasiswa Tahun Pertama}

Hasil penelitian menunjukkan bahwa dari 74 responden, 34 orang $(45,9 \%)$ diataranya tidak mengalami stres (normal). Hal ini berarti hampir setengah dari responden masih dalam batas wajar dalam menghadapi stresnya.Hal ini kemungkinan dapat disebabkan karena menjadi mahasiswa, terutama mahasiswa baru dianggap bukanlah stresor yang dianggap mengancam pada diri mahasiswa. Sebagaimana Chopra \& Dossey (dikutip dalam Seaward, 2011) mendefinisikan bahwa stres adalah ketidakmampuan seseorang dalam mengatasi ancaman secara mental, fisik, emosional, dan spiritual, yang mengakibatkan serangkaian respon fisiologis dan adaptasi.

Hasil penelitian ini sejalan dengan penelitian yang dilakuan oleh Patil, Patkar, \& Patkar (2016) yang menemukan bahwa dari 78 mahasiswa tahun pertama sebanyak 53,85\% tidak mengalami stres. Menjadi mahasiswa baru, tidak dianggap sebagai stresor yang mengancam mereka, karena mereka menganggap bahwa hal ini merupakan suatu proses yang harus dijalani (Bataineh, 2013).

\section{Hubungan Kecerdasan Emosional dengan Tingkat Stres Mahasiswa Tahun Pertama}

Hal ini sejalan dengan penelitian yang dilakukan oleh Forushani \& Besharat (2011) yang menemukan bahwa terdapat hubungan antara 
kecerdasan emosional dengan persepsi stres pada mahasiswa perempuan di Iran. Penelitian yang juga dilakukan oleh Yamani, Shahabi \& Haghani (2014) menemukan hubungan antara kecerdasan emosional dengan stres pekerjaan.

Individu dengan kecerdasan emosional yang tinggi mampu menangani tuntutan lingkungan dengan lebih baik daripada individu dengan kecerdasan emosional yang lebih rendah (Forushani \& Besharat, 2011). Menurut peneliti hal ini kemungkinan dapat disebabkan karena individu dengan kecerdasan emosional yang lebih tinggi lebih sadar akan emosinya dan lebih mampu mengatur emosinya, sehingga stres yang dirasakan dapat berkurang dan secara bersamaan memiliki tingkat kesejahteraan yang lebih baik. Individu dengan kecerdasan emosional yang lebih tinggi memiliki keuntungan dalam kemampuan bersosialisasi yang lebih besar, jaringan sosial yang lebih kaya, dan strategi koping yang lebih efektif, hal ini dapat membuat stres berkurang.

Peran kecerdasan emosional dalam mengurangi stres dapat berpengaruh pada respon psikologisnya.Dimana seseorang yang memiliki kecerdasan emosional yang baik, maka memiliki strategi koping yang baik pula (Mi-Ran \& Su-Jeong, 2015). Strategi koping yang berorientasi pada masalah menghadapi tekanantekanan atau kesulitan-kesulitan dengan cara langsung menghadapi stresor, sehingga memandang diri lebih positif, mampu beradaptasi dengan sumber stres sehingga lebih memiliki motivasi yang tinggi untuk menyelesaikannya dengan cara yang lain, serta mampu mengembangkan keterampilan-keterampilan baru untuk menghadapi serta menyelesaikan masalah sehingga mempunyai dampak menurunkan tingkat stres (Sulistyowati, Wismanto, \& Utami, 2015).

Bagian lain otak emosional memungkinkan adanya respons korektif yang lebih tepat.Di otak, sakelar perekam ledakan amigdala terletak di ujung lain neokorteks, yaitu di lobus-lobus prefrontal tepat di balik dahi.Korteks prefrontal bekerja saat seseorang merasa takut atau marah, tetapi berfungsi pula untuk menghambat atau mengendalikan perasaan agar dapat menangani situasi yang dihadapi dengan lebih efektif. Wilayah neokorteks pada otak menawarkan respons yang lebih analitis atau lebih cocok akan dorongan emosi kita, memodulasi amigdala dan wilayah-wilayah limbik lainnya (Goleman, 2015). Sehingga, seseorang yang mengalami stres, apabila memiliki kecerdasan emosional yang baik, maka dapat lebih berpikir analitis untuk mengatasi stresnya.

\section{Hubungan Dimensi Kecerdasan Emosional dengan Tingkat Stres Mahasiswa Tahun Pertama}

Dari lima dimensi kecerdasan emosional yaitu mengenali emosi diri, mengelola emosi, motivasi, empati, dan membina hubungan dengan orang lain, yang memiliki hubungan dengan stres mahasiswa tahun pertama adalah mengelola emosi dan motivasi. Hasil ini sejalan dengan penelitian yang dilakukan oleh Yamani, Shahabi, Haghani (2014) yang menemukan bahwa manajemen diri memiliki hubungan yang berbanding terbalik dengan tingkat stres. Individu yang memiliki kecerdasan emosional yang tinggi memiliki kemampuan untuk melawan peristiwa dan situasi yang menegangkan. Menurut Goleman, individu yang dapat mengelola dan memahami stres yang dialaminya dapat menghindari emosi negatif seperti putus asa, kecemasan, dan mudah tersinggung.

Penelitian yang dilakukan oleh Pratama \& Prihatiningsih (2014) juga menemukan adanya hubungan yang signikan antara motivasi dengan 
tingkat stres mahasiswa.Motivasi menjadi suatu kekuatan, tenaga atau daya, atau suatu keadaan yang kompleks dan kesiapsediaan dalam diri individu untuk bergerak kearah tujuan tertentu, baik disadari maupun tidak disadari.Motivasi belajar adalah dorongan internal dan eksternal pada diri seseorang yang sedang belajar untuk mengadakan perubahan tingkah laku, pada umumnya dengan beberapa indikator atau unsur yang mendukung. Responden yang memiliki motivasi rendah dengan tingkat stres berat dikarenakan responden merasakan adanya tekanan dari dalam diri responden terhadap tuntutan tugas dan kegiatan yang harus diselesaikan. Responden dengan motivasi tinggi memiliki tingkat stres yang ringan, hal ini dikarenakan adanya keinginan dari mahasiswa untuk mendapatkan nilai yang memuaskan, keinginan untuk mendapatkan suatu penghargaan baik dari lingkungan akademik maupun dari lingkungan keluarga.

\section{KESIMPULAN}

Berdasarkan hasil penelitian dan pembahasan, dapat diperoleh kesimpulan bahwa mahasiswa tahun pertama di PSIK FK UH sebagian besar memiliki kecerdasan emosional sedang, yaitu sebanyak 39 orang $(52,7 \%)$. Tingkat stres pada mahasiswa tahun pertama di PSIK FK UH sebagian besarnya berada pada kategori normal, yaitu sebanyak 34 orang (45,9\%). Ada hubungan antarakecerdasan emosional dengan tingkat stres mahasiswa tahun pertama, dimana semakin tinggi kecerdasan emosional maka tingkat stres semakin rendah.Dimensi dari kecerdasan emosional yang juga berhubungan dengan stres mahasiswa tahun pertama, yaitu kemampuan mengelola emosi dan motivasi diri.

Oleh karena pentingnya kecerdasan emosional tersebut, diharapkan adanya suatu program yang dapat dijadikan sebagai langkah awal dalam pengembangan kecerdasan emosional mahasiswa.

\section{DAFTAR PUSTAKA}

Abdollahi, A., Carlbring, P., Khanbani, M., \& Ghahfarokhdi, S. A. (2016). Emotional intelligence moderates perceived stress and suicidal ideation among depressed adolescent in patients. Personality and Individual Differences, 102, 223-228.

Andriani, H. (2011). Hubungan motivasi belajar dan prestasi akademik mahasiswa S1 Keperawatan Sekolah Tinggi Ilmu Kesehatan Dian Husada Mojokerto. Jurna Keperawatan, 1(1), 1-10.

Asmadi. (2008). Konsep dasar keperawatan. Jakarta: EGC.

Bataineh, M. Z. (2013). Academic stress among undergraduate students: this case of education faculty at King Saud University. International Interdisciplinary Journal of Education, 2(1), 82-88.

Fadilah, M., \& Suleeman, J. (2013). Gambaran kecerdasan emosional mahasiswa Fakultas Psikologi Universitas Indonesia. Depok: Universitas Indonesia.

Forushani, N. Z., \& Besharat, M. A. (2011). Relation between emotional intelligence and perceived stress among female students. Procedia Social and Behavioral Sciences, 30, 1109-1112.

Goleman, D. (2015). Emotional intelligence: Kecerdasan emosional. Jakarta: Gramedia Pustaka Utama.

KBBI. (2016). Mahasiswa. Retrieved from Kamus Besar Bahasa Indonesia (KBBI): http://kbbi.web.id/mahasiswa

Learner, R. M., \& Steinberg, L. (2009). Handbook of adolescent psychology (3 ed., Vol. 1). Canada: John Wiley \& Sons.

Maulana, Z. F., TU, S., F, S., \& JMC, S. (2014). Perbedaan tingkat stres antara mahasiswa tahun pertama dan tahun kedua di Fakultas Kedokteran Universitas Lampung. Jurnal Kedokteran Universitas Lampung, 3(4), 154-162.

Mi-Ran, K., \& Su-Jeong, H. (2015). Nursing students' emotional intelligence and coping strategies. Advanced Sciences and Technology Letters, 88, 53-56.

Nafiati, D. A. (2015). Lingkungan belajar dan kecerdasan emosional sebagai faktor yang mempengaruhi stres kuliah mahasiswa. Jurnal Penelitian dan Wacana Pendidikan, 9(1), 8-12.

Ninggalih, R. (2013, Juni). Stres, gangguan, psikologis, dan hubungannya dengan kondisi fisik. Retrieved September 22, 2016, from Majalah 1000 guru: http:// majalah 1000guru.net/2013/06/stresgangguan-psikologis-fisik/

Nugroho, K. M., Pasiak, T. F., \& Tanudjaja, G. N. (2016). Gambaran empati pada mahasiswa Fakultas Kedokteran Universitas Sam Ratulangi angkatan 2012. Jurnal e-Biomedik, 4(1), 1-7.

Nurliyanti. (2014). Pengaruh terapi tawa 
terhadap tingkat stres mahasiswa semester awal PSIK FK UH. [Skripsi tidak dipublikasikan]. Makassar: Universitas Hasanuddin.

Patil, S. K., Patkar, U. S., \& Patkar, K. U. (2016). Comparision of levels of stress in different years of M.B.B.S student in medical college - an observational study. International Journal of Contemporary Medical Research, 3(6), 1655-1657.

Potter, P. A., \& Perry, A. G. (2005). Buku ajar fundamental keperawatan: konsep proses dan praktek (4 ed., Vol. 1). Jakarta: EGC.

Prasetiyo, A., \& Andriani, I. (2011). Hubungan antara kecerdasan emosi dengan subjective well being pada mahasiswa tingkat pertama. Proceeding PESAT (Psikologi, Ekonomi, Sastra, Arsitektur, \& Sipil), 4, 22-26.

Pratama, M. R., \& Prihatiningsih, D. (2014). Hubungan motivasi akademik dengan tingkat stres akademik mahasiswa keperawatan semester VI Stikes 'Aisyiyah Yogyakarta. Yogyakarta: Stikes 'Aisyiyah.

Reddy, E. A., Venu, V. G., \& Rajana, B. (2015). Perceived stress and prevalence of depression among first-year medical students. Journal of Dr. NTR University of Health Science, 4(4), 209-213.

Santrock, J. W. (2003). Adolescence perkembangan remaja. Jakarta: Erlangga.

Seaward, B. L. (2011). Essentials of managing stress. Jones and Bartlett Publishers.

Sohail, N. (2013). Stress and academic performace among medical students. Journal of the College of Physicians and Surgeons Pakistan, 23(1), 67-71.

Sulistyowati, D. A., Wismanto, Y. B., \& Utami, C. T. (2015). Hubungan antara kecerdasan emosional dan optimisme dengan problem focused coping pada mahasiswa S1 Keperawatan Stikes Telogorejo Semarang. Kajian Ilmiah Psikologi, 4(1), 11-18.

Swarjana, I. K. (2012). Metodologi penelitian kesehatan: Tuntunan praktis pembuatan proposal penelitian. Yogyakarta: ANDI.

Tridhonanto, A. (2009). Melejitkan kecerdasan emosi (EQ) buah hati. Jakarta: Elex Media Komputindo.

Yadav, R., Khanna, A., \& Singh, D. (2016). Exploration of relationship between stress and spirituality characteristics of male and female engineering students: a comprehensive study. Journal of Religion and Health, 55(6), 1-12.

Yamani, N., Shahabi, M., \& Haghani, F. (2014). The relationship between emotional intelligence and job stress in the faculty faculty of medicine in Isafahan University of Medical Sciences. Journal of Advances in Medical Education \& Professionalism, 2(1), 20-26.

Zeidner, M., \& Onlick-Shemesh, D. (2010). Emotional Intelligence and subjective well-being revisited. Personality and Individual Difference, 48, 431-435. 